\title{
Assessment of nutrient use in annual and perennial crops: A functional concept for analyzing nitrogen use efficiency
}

\author{
Martin Weih • Linnéa Asplund • Göran Bergkvist
}

Received: 22 July 2010 /Accepted: 30 September 2010 /Published online: 12 October 2010

(C) The Author(s) 2010. This article is published with open access at Springerlink.com

\begin{abstract}
The use of more nutrient-efficient crops is important for maintaining yields while enhancing environmental sustainability. Various approaches are being applied to evaluate aspects of plant nutrient use efficiency, among them ecological concepts based on accumulation and losses of biomass and nutrients, agronomic concepts with a major focus on agricultural crops and harvested products, and physiological approaches assessing single physiological processes important for nutrient use. Unfortunately, the various approaches are often not compatible. Here we propose, with the example of nitrogen $(\mathrm{N})$ use efficiency (NUE) of cereals, to integrate the functionally important components of NUE in a common conceptual framework. We link productivity to $\mathrm{N}$ in crops and seeds and consider the whole life-cycle of the crop (including seeds). Three major components of NUE are separated: The $\mathrm{N}$ uptake efficiency, grain-specific $\mathrm{N}$ efficiency and grain $\mathrm{N}$ concentration. The three components combine to a measure of overall NUE in terms of the $\mathrm{N}$ yield in harvested grain per unit of $\mathrm{N}$ in seed grain or soil $\mathrm{N}$. The concept can be applied for both annual and perennial
\end{abstract}

Responsible Editor: Hans Lambers.

M. Weih $(\bowtie) \cdot$ L. Asplund $\cdot$ G. Bergkvist

Department of Crop Production Ecology,

Swedish University of Agricultural Sciences,

PO Box 7043, SE-750 07 Uppsala, Sweden

e-mail: martin.weih@vpe.slu.se plants, which is demonstrated with the examples of winter wheat and a perennial energy crop (Salix) grown in Central Sweden.

Keywords Agricultural crops · Growth · Nutrient use efficiency $\cdot$ Nutrients $\cdot$ Salix $\cdot$ Wheat

\section{Introduction}

The main goal of agricultural research traditionally has been to increase crop productivity. However, there are currently increased concerns about environmental sustainability of crop production systems (e.g. biodiversity) as well as the environmental problems caused by the enhanced use of nutrient fertilizers to increase productivity, which goes along with decreased efficiency of fertilizer use (Tilman et al. 2002). In this context, the nutrient use efficiency of crops has acquired great relevance (Fageria et al. 2008; Spiertz and Ewert 2009).

In general, the nutrient use efficiency considers the processes of carbon gain and loss in relation to the processes associated with the gain and loss of the major growth-limiting nutrients. Nitrogen $(\mathrm{N})$ and phosphorus are the nutrients that most frequently limit plant growth, although growth conditions (e.g. temperature) and other resources (e.g. water) might often greatly alter the nutrient limitation.

Nitrogen is often regarded the single most important nutrient. In the agricultural context, nitrogen use 
efficiency (NUE) needs to focus on the specific biomass fractions forming yield, which are defined by the harvested product and related to both the consumption of nutrients and product quality aspects (e.g. protein content). The challenge is to develop a meaningful NUE concept that both allows the analysis of the functionally important NUE components in an agronomic context (yield and quality), and takes advantage of the method developments in growth analysis and functional ecology (cf. Hunt 1982; Ågren 1985; Berendse and Aerts 1987). The objective was to briefly review the existing concepts for the assessment of NUE in different contexts (agronomic, physiological, ecological), and to develop an integrated approach taking advantage of the method developments in the existing NUE concepts and applicable to various crop types (annual and perennial crops).

\section{Cereal growth and nitrogen use efficiency}

The development and growth of agricultural plants, here exemplified by cereals grown in Northern Europe, starts with a period of seedling establishment, tissue differentiation and expansion, during which the growth processes are largely limited by factors other than nutrients (e.g. temperature). The major growth period starts with accelerated seedling growth in spring and ends with the beginning of grain filling. The weeks within the major growth period, which represent the relationship between the accumulation of crop $\mathrm{N}$ and biomass, are most appropriate for evaluation of the functional relationships between crop $\mathrm{N}$ and growth, because major $\mathrm{N}$ limitation of growth can only be expected during this period. The major growth period is followed by a final period characterized by ceased growth and dominated by nutrient and carbohydrate relocation processes, which greatly affect the crop $\mathrm{N}$ dynamics (e.g. "stay-green", Borrell and Hammer 2000). The growth and nutrient uptake processes during the period of major growth are best described by exponential and/or linear functions, reflecting the nature of the growth and uptake patterns during this period (Hunt 1982; Monteith 2000).

Several definitions have been suggested for NUE in crop production. For example, Fageria et al. (2008) defined a nutrient efficient plant as one that produces high economic yield with a given quantity of applied or absorbed nutrient. A common way to assess NUE in crop production is based on the amount of yield produced per unit soil N, as proposed by Moll et al. (1982). In this approach, Moll et al. (1982) separate the NUE into the two components $\mathrm{N}$ uptake efficiency (total plant $\mathrm{N}$ per unit soil $\mathrm{N}$ ) and $\mathrm{N}$ utilization efficiency (grain biomass per unit of total plant $\mathrm{N}$ ). The approach is here exemplified for winter wheat grown in Central Sweden (Table 1) and has recently been used by many authors (e.g. Anbessa et al. 2009; Foulkes et al. 2009; Sylvester-Bradley and Kindred 2009). The concept of Moll et al. (1982) certainly is meaningful in an applied agronomic perspective with focus only on cereals, but has serious limitations especially when the NUE of different crops and production systems should be compared. Another important limitation is that the concept by Moll et al. (1982) does not allow separation of the processes involved in N-limited biomass accumulation during major growth period, grain maturing and $\mathrm{N}$ carry-over from plant to grain, the latter often driven by factors other than nutrients. In addition, the approaches based on Moll et al. (1982) relate biomass accumulation to final crop $\mathrm{N}$ at harvest, and thus assume that the final crop $\mathrm{N}$ is available during the entire period from seed to harvest. This assumption might be adequate in a purely applied perspective focusing on yields in relation to nutrient inputs. However, in more functional and comparative perspectives this assumption makes little sense and therefore causes conceptual problems when integrating with important elements of plant growth theory (e.g. $\mathrm{N}$ productivity, Ågren 1985) and when comparing different crop types.

Table 1 Calculation of nutrient use efficiency and its components according to Moll et al. (1982) using typical data from winter wheat sown at a density of 350 grains $\mathrm{m}^{-2}$ and fertilized with $130 \mathrm{kgNha}^{-1}$ in Central Sweden (G. Bergkvist unpubl.). $N_{t}$ total plant $\mathrm{N}$ at maturity $\left(20.5 \mathrm{gm}^{-2}\right), N_{\text {soil }} \mathrm{N}$ supply from soil including fertilizer and mineralized $\mathrm{N}\left(22 \mathrm{gm}^{-2}\right), G_{w}$ Grain weight at harvest $\left(650 \mathrm{gm}^{-2}\right)$

\begin{tabular}{ll}
\hline Trait & Value $\left(\mathrm{g} \mathrm{g}^{-1}\right)$ \\
\hline Uptake efficiency $\left(N_{t} / N_{\text {soil }}\right)$ & 0.93 \\
Utilization efficiency $\left(G_{w} / N_{t}\right)$ & 31.7 \\
Nutrient use efficiency $\left(N_{t} / N_{\text {soil }} \cdot G_{w} / N_{t}\right)$ & 29.5 \\
\hline
\end{tabular}




\section{Physiological processes controlling nitrogen use efficiency}

Many studies addressing the $\mathrm{N}$ use of crops deal with single physiological characteristics or processes having an impact on the NUE. These processes can involve the source and sink relationships at certain crop stages (Bancal 2009), critical N dilution and crop N deficiency issues (Justes et al. 1994; Lemaire and Gastal 2009), dependence of mineral nutrient stoichiometry on biomass production (Greenwood et al. 2008), root characteristics related to the N metabolism and NUE (Foulkes et al. 2009; Garnett et al. 2009; Pedersen et al. 2010), or the genes affecting aspects of NUE including $\mathrm{N}$ retranslocation and conservation (Waters et al. 2009; Habash et al. 2007; Fontaine et al. 2009). Other research mainly focuses on grain quality, which is affected by soil $\mathrm{N}$ availability (Kindred et al. 2008; Saint Pierre et al. 2008). One particular physiological process has been discussed frequently in the context of NUE: There is great hope to increase the NUE of crops through enhanced efficiency of the photosynthetic system, for example by modifying or selecting for variation in $\mathrm{RuBisCO}$ activity. This approach has been suggested to ultimately result in the utilization of the full potential of cereals in the future (Hibberd et al. 2008; Reynolds et al. 2009). The single processes certainly contribute to and, if combined, constitute the whole plant NUE, but it is the outcome of the processes at the whole plant and community levels, which should deliver the context for the evaluation of the single physiological processes contributing to increased or decreased NUE.

\section{Ecological concepts on nitrogen use efficiency based on plant growth theory}

The first attempts to define NUE in an ecological context considered the plant biomass production in relation to plant-internal $\mathrm{N}$ contents (i.e. inverse of plant $\mathrm{N}$ concentration, Chapin 1980), and related biomass losses to the $\mathrm{N}$ losses at the ecosystem level (Vitousek 1982). At the plant level, the mechanisticfunctional relationship between the contents of the growth-limiting nutrients (here $\mathrm{N}$ ) and biomass production was described by means of the $\mathrm{N}$ productivity concept (Ågren 1985). The N productivity was integrated into a concept, in which the NUE was broken down into the two components of $\mathrm{N}$ productivity (Ågren 1985) and N carry-over from annual to perennial plant parts, i.e., mean residence time of $\mathrm{N}$ (Berendse and Aerts 1987). The mechanistic background of the two components was further analysed and resulted in a number of hypotheses regarding, e.g., the functional relationships between $\mathrm{N}$ productivity and conservation mechanisms in plants (Garnier et al. 1995; Garnier and Aronson 1998; Eckstein et al. 1999).

The approaches have made very valuable contributions to the functional understanding of plant $\mathrm{N}$ use and growth, but the results are frequently difficult to apply in an agronomic context due to lack of focus on the harvested products. In addition, the ecological approaches pay great attention to the evolutionary mechanisms of plant adaptation to nutrient-poor environments and frequently assume that, in an annual perspective, the nutrient uptake equals the nutrient losses (i.e. steady-state conditions, Eckstein et al. 1999; Frissel 1981). These conditions are often less relevant in agriculture. Also, steadily increasing nutrient addition greatly facilitates the analysis of functional relationships in NUE research (Ingestad and Ågren 1995). Such conditions are likely to be met in approximation during some periods in the growth and development of many agricultural crops. In an agricultural context, the critical period(s) during crop growth and development, in which functional growth analysis can be applied (e.g. major growth period), need to be linked to the harvested product and also the $\mathrm{N}$ uptake and carry-over processes before and after the critical period(s).

An integrated NUE approach also should contain a component allowing the consideration of $\mathrm{N}$ carry-over and conservation over more than a single growing season, e.g. for assessment of the NUE of perennial crops. This aspect was recognised by Dawson et al. (2008), suggesting the calculation of the amount of $\mathrm{N}$ carried over to the following year as part of an integrated NUE concept especially for perennial crops. However, a general NUE concept should consist of the same components for all agricultural crops, irrespective their annual or perennial nature. In ecological NUE concepts, $\mathrm{N}$ resorption, e.g. from senescing leaves, is usually considered an important component of $\mathrm{N}$ conservation and calculated from the perspective of 
the perennial plant parts to which the nutrients are retranslocated from the annual plant parts (Eckstein et al. 1999). The only perennial plant parts in annual plants, among them many agricultural crops, are the seeds, which in an agricultural context often represent the major harvest product. Consequently, it appears most meaningful to here define resorption efficiency from the perspective of the harvested product, e.g. grains in cereals, where resorption efficiency affects the amount of biomass and $\mathrm{N}$ allocated to grains and the grain $\mathrm{N}$ content, which influences grain quality. For example, $\mathrm{N}$ relocation to grains usually exceeds $\mathrm{N}$ uptake and assimilation by the crop during grain filling in cereals (Spiertz and De Vos 1983).

\section{A concept linking productivity to nitrogen in crop plants and seeds}

We propose a concept for the assessment of NUE in agricultural crops, which considers the whole lifecycle of the crop (including seeds, Liptay and Arevalo 2000), can be applied for both annual and perennial crops, and offers the possibility to link important elements of growth theory (i.e., $\mathrm{N}$ productivity, $\mathrm{N}$ conservation) to important issues in agriculture, i.e., crop yield and quality. The approach is outlined with the example of cereals grown in an environment, in which $\mathrm{N}$ is among the major growth-limiting factors. Adjustment to other types of crops and growth limitations should be possible.

Conceptually similar to other NUE approaches based on, e.g., Moll et al. (1982), we consider the $\mathrm{N}$ uptake efficiency $\left(U_{N}\right)$ and $\mathrm{N}$ utilization efficiency (here grainspecific $\mathrm{N}$ efficiency, $E_{N}, g$ ) as important components of the NUE (Box 1), but we re-define the components. A numerical comparison of the proposed concept with the approach by Moll et al. (1982) is illustrated by using typical data from winter wheat grown in central Sweden (Tables 1 and 2). As a third component of NUE, we add the $\mathrm{N}$ concentration of grains at harvest $\left(C_{N}, g\right)$, which recognises the aspects of $\mathrm{N}$ carry-over from vegetative plant parts to grain as components of NUE. For example, the genetic regulation of nutrient remobilization (Waters et al. 2009) could be evaluated in a broader NUE context when using the concept
Table 2 Comparison of $\mathrm{N}$ use efficiency (NUE), soil-specific $\mathrm{N}$ use efficiency $\left(\mathrm{NUE}_{\mathrm{soil}}\right)$ and their components for winter wheat and Salix short rotation coppice (SRC) grown on agricultural land in Central Sweden and according to the NUE concept presented in Box 1 . The $\mathrm{N}$ productivity during major growth period was calculated according to Ågren (1985) only for Salix, because no suitable whole-plant dry weight data were available for wheat. The same data as for Table 1 was used for wheat and the calculation of plant $\mathrm{N}$ at start and end of major growth period was based on the assumption that $10 \%$ and $80 \%$ of the final plant $\mathrm{N}\left(20.5 \mathrm{~g} \mathrm{Nm}^{-2}\right)$ was found in the crop at start and end of a 6-week major growth period. The Salix data are based on means of biomass and $\mathrm{N}$ assessments across 6 Salix varieties field-grown in the third year of the first cutting cycle (fertilized and non-irrigated treatment, Weih and Nordh 2005). The major growth period in the Salix SRC lasted from May to September (16 weeks), and further details of the Salix data are found in Weih and Nordh (2005). "Yield" is grain in wheat and harvested shoot biomass in Salix. "Perennial N" $\left(N_{s}\right.$ in Box 1) is seed grain $\mathrm{N}$ in wheat and shoot $\mathrm{N}$ at the end of the previous growing season in Salix. N' is mean plant N during major growth period

\begin{tabular}{|c|c|c|}
\hline Trait & Winter wheat & Salix SRC \\
\hline $\mathrm{N}$ uptake efficiency $U_{N}\left(\mathrm{~N}^{\prime} /\right.$ perennial $\left.\mathrm{N}, \mathrm{g} \mathrm{g}^{-1}\right)$ & 28.8 & 4.1 \\
\hline Soil-specific $\mathrm{N}$ uptake efficiency $U_{N \text {, soil }}\left(\mathrm{g} \mathrm{g}^{-1}\right)^{\mathrm{a}}$ & 0.40 & 0.44 \\
\hline Yield-specific $\mathrm{N}$ efficiency $E_{N, \text { yield }}$ (grain or biomass yield/N', $\mathrm{g} \mathrm{g}^{-1}$ ) & 70.5 & 160.3 \\
\hline $\mathrm{N}$ concentration in grain or biomass yield $C_{N, \text { yield }}\left(\mathrm{g} \mathrm{g}^{-1}\right)$ & 0.0202 & 0.0054 \\
\hline$N U E\left(N_{\text {yield }} /\right.$ perennial $\left.\mathrm{N} ; \mathrm{g} \mathrm{g}^{-1}\right)$ & 41.0 & 3.5 \\
\hline$N U E_{\text {soil }}\left(N_{\text {yield }} /\right.$ soil $\left.\mathrm{N} ; \mathrm{g} \mathrm{g}^{-1}\right)$ & 0.57 & 0.38 \\
\hline Relative $\mathrm{N}$ accumulation rate $R_{N}\left(\right.$ week $\left.^{-1}\right)$ & 0.35 & 0.09 \\
\hline $\mathrm{N}$ productivity $\left(R_{N} \cdot \mathrm{d} W / \mathrm{d} N^{\mathrm{b}} ; \mathrm{g} \mathrm{g}^{-1}\right.$ week $\left.^{-1}\right)$ & - & 13.7 \\
\hline
\end{tabular}

${ }^{\text {a }}$ Calculation in analogy to Box 1: $\left(N^{\prime}-N_{s}\right) /$ soil N, where $N_{s}$ is the perennial $\mathrm{N}$ fraction

${ }^{\mathrm{b}}$ Increase in total dry weight $(\mathrm{d} W)$ and $\mathrm{N}$ pool during major growth period $\left(\mathrm{d} N{ }^{\prime}\right)$ 
proposed here. The three components combined, result in the NUE as an expression of the amount of $\mathrm{N}$ in the harvested product (i.e. grains) per unit of $\mathrm{N}$ content in seed grains, and thereby span the whole life-cycle of the crop from seed to harvested grain product, which represents the seed for the next crop generation.

The mean $\mathrm{N}$ uptake efficiency $\left(U_{N}\right)$ is the mean $\mathrm{N}$ content during major growth period, in relation to the $\mathrm{N}$ content in seed grain. The $U_{N}$ thus reflects the capacity of seed grain $\mathrm{N}$ to generate plant structures for the exploitation of soil $\mathrm{N}$ during a period most important for the functional relationship between $\mathrm{N}$ and biomass accumulation. The components of $\mathrm{N}$ uptake efficiency $\left(U_{N}\right)$ include the mean $\mathrm{N}$ accumulation rate during the period of major growth $\left(R_{N}\right)$, as well as the duration $(t)$ of this critical period for cereal development. The $U_{N}$ as calculated here is based on the major growth period and thus not directly comparable with the $\mathrm{N}$ uptake efficiency defined by Moll et al. (1982) (Table 1). However, the $\mathrm{N}$ uptake efficiency sensu Moll et al. (1982) could be calculated by using components of the proposed concept, i.e., the ratio $B_{g} / N$ (Box 1). In the calculation of $U_{N}$, the seed $\mathrm{N}$ can be replaced by fertilizer or soil $\mathrm{N}$ to obtain a measure of the $\mathrm{N}$ uptake and, ultimately, NUE on basis of fertilizer or soil $\mathrm{N}$.

The grain-specific $\mathrm{N}$ efficiency $\left(E_{N}, g\right)$ is calculated as the amount of grain biomass produced per unit of mean plant $\mathrm{N}$ content during the major growth period, with the methods commonly used in growth analysis (Hunt 1982). In cereals, the major growth period can be defined as the period from the start of accelerated plant growth in spring to the start of grain filling (Zadoks et al. 1974). The evaluation of $E_{N, g}$ should reflect the functional relationships between crop $\mathrm{N}$ and biomass accumulation and therefore needs to be based on the mean $\mathrm{N}$ content during the major growth period. Nitrogen uptake and carry-over processes before and after the defined weeks within the major growth period can be considered in the concept by the other components and additional calculations. For example, the plant $\mathrm{N}$ dynamics relevant for grain filling in the growth stages after the major growth period and flowering (e.g. "stay-green", Borrell and Hammer 2000) could be investigated by monitoring leaf $\mathrm{N}$ contents and calculating the difference between the plant $\mathrm{N}$ content at the end of major growth period and final harvest (i.e. $N_{t}-N_{f}^{\prime}$, Box 1). The components of grain-specific $\mathrm{N}$ efficiency $\left(E_{N}, g\right)$ include the $\mathrm{N}$ efficiency of the whole plant $\left(E_{N}\right)$, and the harvest index, which is the biomass allocation to the harvested product (i.e. grains; $r_{B}, g$ ). If compared with the utilization efficiency defined by Moll et al. (1982), the calculation of the grain-specific $\mathrm{N}$ efficiency $\left(E_{N}, g\right)$ according to Box 1 indicates a higher efficiency (Tables 1 and 2). The greater efficiency arises because the $E_{N, g}$ is calculated on basis of the mean $\mathrm{N}$ during major growth period, which is more meaningful in a functional perspective, instead of the final $\mathrm{N}$ content used for the calculation of utilization efficiency by Moll et al. (1982).

The grain $\mathrm{N}$ concentration at final harvest $\left(C_{N}, g\right)$ reflects $\mathrm{N}$ carry-over from vegetative plant parts to grains. The components of the grain $\mathrm{N}$ concentration $\left(C_{N}, g\right)$ inform about the efficiency of $\mathrm{N}$ carry-over from whole-plants to grains $\left(r_{N}, g\right)$, sometimes called $\mathrm{N}$-yield. The $C_{N, g}$ could be replaced by the concentrations of other relevant components in the harvested grains (e.g. starch), to obtain a NUE measure expressing the yield of the component of interest per unit of seed $\mathrm{N}$ (or soil $\mathrm{N}$, if seed $\mathrm{N}$ is replaced by soil $\mathrm{N}$, see above). The concept can thus be adjusted to the NUE evaluation of feedstock production for various purposes including biofuels (cf. Spiertz and Ewert 2009), for which the grain $\mathrm{N}$ concentration might be less relevant.

\section{Comparison of NUE in annual and perennial crops}

Maximising the efficiency of crop resource use will be a highly prioritized issue in agricultural research, and concepts allowing the comparison of resource use efficiency across different crop types are therefore needed. For example, there is increasing evidence that perennial cropping systems can utilize many resources more efficiently than annual systems (Jordan et al. 2007), but quantitative comparisons of resource use efficiency between the different crops are difficult. The proposed NUE concept for cereals (Box 1) allows great flexibility and can also be used to assess the NUE in perennial crops. Thus, the $\mathrm{N}$ content in seed grains of cereals (Box 1) can in perennial crops be replaced by the $\mathrm{N}$ content of the 
perennial plant parts to allow for annual calculations of the NUE and its components. Here we exemplify perennial crops with a biomass crop (Salix) grown in short rotation (c. 3 year cutting cycle) on agricultural land for energy purposes. These perennial biomass crops possibly could replace conventional agricultural crops in many areas world-wide in the near future (Hoogwijk et al. 2003), which makes this an interesting comparison.

The comparison between the annual winter wheat and the perennial Salix short rotation coppice (SRC) shows higher overall NUE in the annual, due to higher $\mathrm{N}$ uptake efficiency $\left(U_{N}\right)$ and $\mathrm{N}$ concentration in the yield $\left(C_{N}\right.$, yield; yield is grain in wheat and harvested shoots in Salix) (Table 2). In contrast, the yield-specific $\mathrm{N}$ efficiency $\left(E_{N}\right.$, yield $)$ was higher in the perennial Salix. When the N uptake efficiency was calculated on basis of soil $\mathrm{N}\left(U_{N}\right.$, soil), the two cropping systems were similar, resulting in similar soil-N based NUE (NUE $E_{\text {soil }}$, Table 2). The large difference in relative $\mathrm{N}$ accumulation rate $\left(R_{N}\right)$ during the major growth period was, to a large extent, cancelled out by the difference in the duration of the major growth period. Thus, the $\left(R_{N}\right)$ was four times higher in wheat than in Salix, whereas its total relative $\mathrm{N}$ accumulation was just 1.5 times higher. The example demonstrates that the proposed concept (Box 1) can be applied to assess the functional relationships of NUE components across different crop types. In addition, the concept is compatible with growth analysis and the $\mathrm{N}$ productivity concept (Ågren 1985), because N productivity can easily be calculated based on the $R_{N}$ (Table 2).

In future, we need to integrate the research performed to evaluate the different aspects of crop NUE at the molecular, single-plant and agro-ecosystem levels with the needs of applied agronomic research, including the selection and breeding of cultivars for low-input and organic cropping systems (Dawson et al. 2008; Spiertz and Ewert 2009). The proposed concept could contribute to such integration by offering a common basis for the evaluation of the various crop types and research activities dealing with different NUE aspects. Therefore, the concept offers great flexibility to be applied to different crops (food, energy, annual, perennial) and in various contexts, e.g. the assessment of NUE based on seed, soil or fertilizer $\mathrm{N}$.

\section{Box 1: Proposal of a functional NUE concept for cereals}

The overall crop nitrogen use efficiency (NUE) is the $\mathrm{N}$ content of produced grain per unit of $\mathrm{N}$ content in seed grain $\left(\mathrm{gN}\left(\mathrm{gN}^{-1}\right)\right.$, and broken down into three major components:

$N U E=U_{N} \cdot E_{N, g} \cdot C_{N, g}$

The mean $\mathrm{N}$ uptake efficiency $\left(U_{N}\right)$ is the mean $\mathrm{N}$ content during major growth period per unit $\mathrm{N}$ content in seed grain $\left(\mathrm{gN}(\mathrm{gN})^{-1}\right)$. In the calculation of $U_{N}$, the seed $\mathrm{N}\left(N_{s}\right)$ can be replaced by fertilizer or soil $\mathrm{N}$ to obtain a measure of the $\mathrm{N}$ uptake and, ultimately, NUE on basis of fertilizer and/or soil N. The grainspecific $\mathrm{N}$ efficiency $\left(E_{N, g}\right)$ reflects the grain biomass produced per unit of mean plant $\mathrm{N}$ content during major growth period ( $\mathrm{g}$ biomass $(\mathrm{gN})^{-1}$ ), and the grain $\mathrm{N}$ concentration $\left(C_{N, g}\right)$ reflects $\mathrm{N}$ conservation or storage ( $\mathrm{gN}$ (g biomass) $\left.{ }^{-1}\right)$. The grain $\mathrm{N}$ concentration $\left(C_{N, g}\right)$ could be replaced by the concentrations of other relevant components, to obtain a NUE measure expressing the yield of the component of interest per unit of seed $\mathrm{N}$ (or soil $\mathrm{N}$, if seed $\mathrm{N}$ is replaced by soil $\mathrm{N}$, see above).

The major components are separated into minor components:

$U_{N}=\frac{N_{i}^{\prime}}{N_{s}}+\frac{\frac{N_{i}^{\prime}}{N_{s}}\left(e^{R_{N} \cdot t}-1\right)}{2}$, where $R_{N} \frac{\ln N_{f}^{\prime}-\ln N_{i}^{\prime}}{t}$

divides the $U_{N}$ into the $\mathrm{N}$ uptake efficiency prior to major growth period and the relative $\mathrm{N}$ uptake rate during major growth period $\left(R_{N}\right)$;

$E_{N, g}=E_{N} \cdot r_{B, g}$

allows the analysis of relationships between $E_{N, g}$, whole-plant $\mathrm{N}$ efficiency and biomass allocation to grains (i.e., harvest index);

$C_{N, g}=C_{N} \frac{r_{N, g}}{r_{B, g}}$

facilitates insight into $\mathrm{N}$ conservation aspects.

The measures refer to ground area basis and year, e.g. $\mathrm{N}$ content of seed grains in $\mathrm{gm}^{-2} \mathrm{year}^{-1}$, if not specified differently. 


\begin{tabular}{|c|c|}
\hline \\
\hline \multicolumn{2}{|c|}{$\begin{array}{l}\text { Symbols used in the equations: } \\
B \quad \text { plant biomass at final }\end{array}$} \\
\hline$B_{g}$ & $\begin{array}{l}\text { biomass of produced grains at final } \\
\text { harvest }(\mathrm{g})\end{array}$ \\
\hline$C_{N}$ & $\begin{array}{l}\text { plant } \mathrm{N} \text { concentration at final harvest } \\
\left(\frac{N}{B} ; \mathrm{g} \mathrm{g}^{-1}\right)\end{array}$ \\
\hline$C_{N, g}$ & $\begin{array}{l}\text { grain } \mathrm{N} \text { concentration at final harvest } \\
\left(\frac{N_{g}}{B_{g}} ; \mathrm{g} \mathrm{g}^{-1}\right)\end{array}$ \\
\hline$E_{N}$ & plant $\mathrm{N}$ effíciency $\left(\frac{B}{N^{\prime}} ; \mathrm{g} \mathrm{g}^{-1}\right)$ \\
\hline$E_{N, g}$ & grain-specific $\mathrm{N}$ efficiency $\left(\frac{B_{g}}{N^{\prime}} ; \mathrm{g} \mathrm{g}^{-1}\right)$ \\
\hline$N$ & plant $\mathrm{N}$ content at final harvest $(\mathrm{g})$ \\
\hline$N_{s}$ & $\mathrm{~N}$ content of seed grain $(\mathrm{g})$ \\
\hline$N_{g}$ & $\begin{array}{l}\mathrm{N} \text { content of produced grain at final } \\
\text { harvest }(\mathrm{g})\end{array}$ \\
\hline$N^{\prime}$ & $\begin{array}{l}\text { mean plant } \mathrm{N} \text { content during major growth } \\
\text { period }\left(\frac{N_{i}^{\prime}+N_{f}^{\prime}}{2} ; \mathrm{g}\right)\end{array}$ \\
\hline$N^{\prime}{ }_{i}$ & $\begin{array}{l}\text { initial plant } \mathrm{N} \text { content at the beginning of } \\
\text { major growth period }(\mathrm{g})\end{array}$ \\
\hline$N_{f}^{\prime}$ & $\begin{array}{l}\text { final plant } \mathrm{N} \text { content at the end of major } \\
\text { growth period }(\mathrm{g})\end{array}$ \\
\hline NUE & nutrient (here N) use efficiency $\left(\frac{N_{g}}{N_{s}} ; \mathrm{g} \mathrm{g}^{-1}\right)$ \\
\hline$R_{N}$ & $\begin{array}{l}\text { mean relative } \mathrm{N} \text { accumulation rate during } \\
\text { major growth period }\left(\frac{\ln N_{f}^{\prime}-\ln N_{i}^{\prime}}{t} ; \mathrm{d}^{-1}\right. \\
\left.\text { or week }{ }^{-1}\right)\end{array}$ \\
\hline$r_{B, g}$ & $\begin{array}{l}\text { grain biomass allocation at final harvest } \\
\left(\frac{B_{g}}{B}\right) \text {, equal to the harvest index }\end{array}$ \\
\hline$r_{N, g}$ & $\begin{array}{l}\text { grain } \mathrm{N} \text { allocation at final harvest }\left(\frac{N_{g}}{N}\right) \text {, } \\
\text { sometimes called ' } \mathrm{N} \text { harvest index' }\end{array}$ \\
\hline$t$ & $\begin{array}{l}\text { duration of major growth period (days or } \\
\text { weeks) }\end{array}$ \\
\hline$U_{N}$ & $\begin{array}{l}\text { mean } \mathrm{N} \text { uptake efficiency during major } \\
\text { growth period per } \mathrm{N} \text { content in seed grain } \\
\left(\frac{N^{\prime}}{N_{s}} ; \mathrm{g} \mathrm{g}^{-1}\right)\end{array}$ \\
\hline
\end{tabular}

Acknowledgements We thank GI Ågren for inspiring discussions and constructive comments to the manuscript.

Open Access This article is distributed under the terms of the Creative Commons Attribution Noncommercial License which permits any noncommercial use, distribution, and reproduction in any medium, provided the original author(s) and source are credited.

\section{References}

Ågren GI (1985) Theory for growth of plants derived from the nitrogen productivity concept. Physiol Plant 64:17-28. doi:10.1111/j.1399-3054.1985.tb01207.x
Anbessa Y, Juskiw P, Good A, Nyachiro J, Helm J (2009) Genetic variability in nitrogen use efficiency of Spring Barley. Crop Sci 49:1259-1269. doi:10.2135/cropsci2008.09.0566

Bancal P (2009) Decorrelating source and sink determinism of nitrogen remobilization during grain filling in wheat. Ann Bot 103:1315-1324. doi:10.1093/aob/mcp077

Berendse F, Aerts R (1987) Nitrogen-use efficiency: a biologically meaningful definition? Func Ecol 1:293-296

Borrell AK, Hammer GL (2000) Nitrogen dynamics and the physiological basis of stay-green in Sorghum. Crop Sci 40:1295-1307. doi:10.2135/cropsci2000.4051295x

Chapin FS III (1980) The mineral nutrition of wild plants. Ann Rev Ecol Syst 11:233-260. doi:10.1146/annurev. es.11.110180.001313

Dawson JC, Huggins DR, Jones SS (2008) Characterizing nitrogen use efficiency in natural and agricultural ecosystems to improve the performance of cereal crops in lowinput and organic agricultural systems. Field Crops Res 107:89-101. doi:10.1016/j.fcr.2008.01.001

Eckstein RL, Karlsson PS, Weih M (1999) Leaf life span and nutrient resorption as determinants of plant nutrient conservation in temperate-arctic regions. New Phytol 143:177-189. doi:10.1046/j.1469-8137.1999.00429.x

Fageria NK, Baligar VC, Li YC (2008) The role of nutrient efficient plants in improving crop yields in the twenty first century. J Plant Nutr 31:1121-1157. doi:10.1080/ 01904160802116068

Fontaine JX, Ravel C, Pageau K, Heumez E, Dubois F, Hirel B, Le Gouis J (2009) A quantitative genetic study for elucidating the contribution of glutamine synthetase, glutamate dehydrogenase and other nitrogen-related physiological traits to the agronomic performance of common wheat. Theor Appl Genet 119:645-662. doi:10.1007/ s00122-009-1076-4

Foulkes MJ, Hawkesford MJ, Barraclough PB, Holdsworth MJ, Kerr S, Kightley S, Shewry PR (2009) Identifying traits to improve the nitrogen economy of wheat: recent advances and future prospects. Field Crops Res 114:329-342. doi:10.1016/j.fcr.2009.09.005

Frissel MJ (1981) The definition of residence times in ecological models. Ecol Bull 33:117-122

Garnett T, Conn V, Kaiser BN (2009) Root based approaches to improving nitrogen use efficiency in plants. Plant Cell Environ 32:1272-1283. doi:10.1111/j.1365-3040.2009. 02011.x

Garnier E, Aronson J (1998) Nitrogen-use efficiency from leaf to stand level: clarifying the concept. In: Lambers $\mathrm{H}$ et al (eds) Inherent variation in plant growth. Physiological mechanisms and ecological consequences. Bakhuys, Amsterdam, pp 515-538

Garnier E, Gobin O, Poorter H (1995) Nitrogen productivity depends on photosynthetic nitrogen use efficiency and nitrogen allocation within the plant. Ann Bot 76:667-672. doi:10.1006/anbo.1995.1145

Greenwood DJ, Karpinets TV, Zhang K, Bosh-Serra A, Boldrini A, Karawulowa L (2008) A unifying concept for the dependence of whole-crop N:P ratio on biomass: theory and experiment. Ann Bot 102:967-977. doi:10.1093/ aob/men 188

Habash DZ, Bernard S, Schondelmaier J, Weyen J, Quarrie SA (2007) The genetics of nitrogen use in hexaploid wheat: $N$ 
utilisation, development and yield. Theor Appl Genet 114:403-419. doi:10.1007/s00122-006-0429-5

Hibberd JM, Sheehy JE, Langdale JA (2008) Using C-4 photosynthesis to increase the yield of rice-rationale and feasibility. Curr Opin Plant Biol 11:228-231. doi:10.1016/j. pbi.2007.11.002

Hoogwijk M, Faaij A, van den Broek R, Berndes G, Gielen D, Turkenburg W (2003) Exploration of the ranges of the global potential of biomass for energy. Biomass Bioenergy 25:119-133. doi:10.1016/S0961-9534(02)00191-5

Hunt R (1982) Plant growth curves - the functional approach to plant growth analysis. Edward Arnold, London

Ingestad T, Ågren GI (1995) Plant nutrition and growth: basic principles. Plant Soil 169:15-20. doi:10.1007/BF00029309

Jordan N, Boody G, Broussard W, Glover JD, Keeney D, McCown BH, McIsaac G, Muller M, Murray H, Neal J, Pansing C, Turner RE, Warner K, Wyse D (2007) Sustainable development of the agricultural bio-economy. Science 316:1570-1571. doi:10.1126/science.1141700

Justes E, Mary B, Meynard JM, Machet JM, Thelier-Huche L (1994) Determination of a critical nitrogen dilution curve for winter wheat crops. Ann Bot 74:397-407. doi:10.1006/ anbo.1994.1133

Kindred DR, Verhoeven TM, Weightman RM, Swanston JS, Aguc RC, Brosnan JM, Sylvester-Bradley R (2008) Effects of variety and fertiliser nitrogen on alcohol yield, grain yield, starch and protein content, and protein composition of winter wheat. J Cereal Sci 48:46-57. doi:10.1016/j.jcs.2007.07.010

Lemaire G, Gastal F (2009) Quantifying crop responses to nitrogen deficiency and avenues to improve nitrogen use efficiency. In: Sadras VO, Calderini DF (eds) Crop physiology: applications for genetic improvement and agronomy. Associated, London, pp 171-199

Liptay A, Arevalo AE (2000) Plant mineral accumulation, use and transport during the life cycle of plants: a review. Can J Plant Sci 80:29-38

Moll RH, Kamprath EJ, Jackson WA (1982) Analysis and interpretation of factors which contribute to efficiency of nitrogen utilization. Agron J 74:562-564. doi:10.2134/ agronj1982.00021962007400030037x
Monteith JL (2000) Fundamental equations for growth in uniform stands of vegetation. Agr For Meteorol 104:511. doi:10.1016/S0168-1923(00)00143-X

Pedersen A, Zhang K, Thorup-Kristensen K, Jensen LS (2010) Modelling diverse root density dynamics and deep nitrogen uptake-A simple approach. Plant Soil 326:493-510. doi:10.1007/s11104-009-0028-8

Reynolds M, Foulkes MJ, Slafer GA, Berry P, Parry MAJ, Snape JW, Angus WJ (2009) Raising yield potential in wheat. J Exp Bot 60:1899-1918. doi:10.1093/jxb/erp016

Saint Pierre C, Peterson CJ, Ross AS, Ohm J, Verhoeven MC, Larson M, Hoefer B (2008) White wheat grain quality changes with genotype, nitrogen fertilization, and water stress. Agron J 100:414 420. doi:10.2134/agrojn12007.0166

Spiertz JHJ, De Vos NM (1983) Agronomical and physiological aspects of the role of nitrogen in yield formation of cereals. Plant Soil 75:379-391. doi:10.1007/BF02369972

Spiertz JHJ, Ewert F (2009) Crop production and resource use to meet the growing demand for food, feed and fuel: opportunities and constraints. NJAS-Wageningen J Life Sci 56:281-300. doi:10.1016/S1573-5214(09)80001-8

Sylvester-Bradley R, Kindred DR (2009) Analysing nitrogen responses of cereals to prioritize routes to the improvement of nitrogen use efficiency. J Exp Bot 60:1939-1951. doi:10.1093/jxb/erp116

Tilman D, Cassman KG, Matson PA, Naylor R, Polasky S (2002) Agricultural sustainability and intensive production practices. Nature 418:671-677. doi:10.1038/nature01014

Vitousek P (1982) Nutrient cycling and nutrient use efficiency. Am Nat 119:553-572. doi:10.1086/283931

Waters BM, Uauy C, Dubcovsky J, Grusak MA (2009) Wheat (Triticum aestivum) NAM proteins regulate the translocation of iron, zinc, and nitrogen compounds from vegetative tissues to grain. J Exp Bot 60:4263-4274. doi:10.1093/jxb/erp257

Weih M, Nordh N-E (2005) Determinants of biomass production in hybrid willows and the prediction of field performance from pot studies. Tree Physiol 25:1197-1206, PMid: 15996963

Zadoks JC, Chang TT, Konzak CF (1974) A decimal code for the growth stages of cereals. Weed Res 14:415-421. doi:10.1111/j.1365-3180.1974.tb01084.x 